\title{
Tillage and Nitrogen Fertilization Effect on Wheat Yield, and Soil Organic Carbon and Total Nitrogen
}

\author{
Muhammad lqbal, Abdul Ghaffar Khan*, Rashid Mukhtar', and Sajid Hussain \\ Institute of Soil and Environmental Sciences, University of Agriculture, Faisalabad 38040, Pakistan
}

Received: ???, 2013 / Accepted: January 5, 2014

\begin{abstract}
Carbon sequestration and increases in soil organic matter have direct positive impacts on soil quality and fertility. This two-year study was conducted to evaluate effect of tillage (zero, minimum, conventional and deep tillage) and nitrogen fertilizer (N@0, 130, 160 and $190 \mathrm{~kg} \mathrm{ha}^{-1}$ ) on wheat yield, carbon and nitrogen sequestration capacity, and soil organic carbon and nitrogen concentrations. The results show that tillage practices had a statistically significant effect on soil organic carbon and total nitrogen at different soil depths; soil organic carbon decreased with depth. Zero tillage treatments had a highly significant soil organic carbon than those of minimum, conventional and deep tillage treatments. Zero tillage treatments had higher soil organic carbon storage in the cultivated layer $(0-15 \mathrm{~cm})$ than the tillage treatments.
\end{abstract}

Keywords: Zero tillage; soil organic carbon; total nitrogen; storage; wheat

*Corresponding author: ghaffarniazi@gmail.com

\section{Introduction}

Increases in atmospheric $\mathrm{CO}_{2}$ levels during the recent decades triggered human's interests of using the soil as a potential soil organic carbon (SOC) sink. The world's soils store about $1500 \mathrm{Gt}$ of organic carbon, almost twice the amount of $\mathrm{C}$ in the atmosphere (Schlesinger, 2000); however, world's oceans contain $38,000 \mathrm{Gt}$ of $\mathrm{C}$. Land use changes and increased fossil fuel combustion are the major causes of $\mathrm{CO}_{2}$ increase in the atmosphere. Soil plowing resulted in substantial increase of soil carbon losses; tilled soils are considered carbon depleted reservoir that can be refilled (Reicosky, 2003). Intensive tillage of agricultural soils has led to considerable losses of soil $\mathrm{C}$ that range from 30 to $50 \%$ (Davidson and Ackerman, 1993). These $\mathrm{CO}_{2}$ losses are related to soil management and fracturing which enhance $\mathrm{CO}_{2}$ emission and oxygen consumption. Global warming can be alleviated through enhancing sequestration of carbon and nitrogen in the soil; in other words, diminishing greenhouse gas emission, such as $\mathrm{CO}_{2}$ and $\mathrm{N}_{2} \mathrm{O}$ (Lal, 2010). Soil $\mathrm{C}$ sequestration is a viable near-term option to mitigate increased atmospheric $\mathrm{CO}_{2}$ because it is relatively a low cost option that can be rapidly deployed across large areas (Caldeira et al., 2004). One of the practices to enhance sequestration of carbon and nitrogen in soil is conservation tillage, defined as any tillage system that leaves sufficient crop residue in place to cover at least $30 \%$ of the soil surface after planting (Lal, 2003). Fabrizzi et al. (2005) found that conservation tillage technology plays a vital role in improving soil physical and chemical properties. Lal and Kimble, (1997) reported that no-till can sequester atmospheric $\mathrm{CO}_{2}$ by $0.1 \% \mathrm{ha}^{-1}$ at the top $0-5 \mathrm{~cm}$ soil depth every year. Sequestration of $C$ in the soil through NT can also conserve $N$, because soil organic $C(S O C)$ and total $N(S T N)$ levels are highly related and similarly impacted by conventional tillage (Franzluebbers et al., 1999; Sainju et al., 2002). Adequate N fertilization is needed to ensure optimum crop productivity and crop residue returns to soils. Sainju et al. (2002) found that $N$ 
fertilization results in more SOC and STN in tilled and non-tilled soils as a result of an increase in the crop residue returned to the soil. Ishaq et al. (2002) found that $\mathrm{N}$ fertilizer application profoundly increases N, P, K and SOC concentrations in the surface layer than in the subsoil. Campbell et al. (2000) found that adequate $\mathrm{N}$ fertilizer application under semiarid climates results in a substantial increase of SOC. They also found that fertilization has a significant effect on soil organic $C$ and total $N$, mineralizable $\mathrm{N}$ and wet aggregate stability. The influence of tillage on SOC and STN can interact with $\mathrm{N}$ fertilization rates (Sainju et al., 2002). Conservation tillage and nitrogen fertilization can improve $C$ and $\mathrm{N}$ storage in the surface soil (Allmaras et al., 2000; Sainju et al., 2006), while conventional tillage and $\mathrm{N}$ fertilization decreases soil organic matter level by increasing carbon and nitrogen mineralization and limiting $C$ and $N$ inputs (Balesdent et al., 1990; Cambardella and Elliott, 1993). However, for soil profile below $7.5-\mathrm{cm}$ depth, tilled soil may have more SOC and STN than soils under conservation tillage due incorporation of residue at greater depths (Clapp et al., 2000). The significance of increased soil organic carbon is its effect on improving soil physical properties, restoring water, and enhancing nutrients availability. These enhancements should ultimately lead to greater biomass and crop yield (Onemli 2004).

The response of wheat yield, and SOC and STN to tillage and inorganic fertilization under semiarid conduction in Pakistan were not investigated before. Thus, the objectives of this study were to: (1) examine the effects of tillage and inorganic $N$ fertilization SOC, STN and wheat yield in semiarid climate of Pakistan; (2) and quantify their effects on soil $C$ and $N$ storage.

\section{Materials and Methods}

A Field study was conducted on the Research Farm of the Institute of Soil and Environmental Sciences, University of Agriculture, Faisalabad, Pakistan ( $31^{\circ} 26^{\prime} \mathrm{N} ; 73^{\circ} 06^{\prime} \mathrm{E}$, and altitude of $184.4 \mathrm{~m})$, to evaluate the effects of tillage and nitrogen levels on soil organic carbon, soil total nitrogen, soil $C$ and $N$ storage and the yield of wheat for two years. The existing farming system in this region is predominantly based on rotations which includes irrigated maize, wheat, cotton, sugarcane, rice, fodder, and pulses.

The soil of the study area is a well-drained Hafizabad sandy clay loam (mixed, semi-active, isohyperthermic Typic Calciargids, based on USDA soil classification) and contains 530, 210, 260 $\mathrm{g} \mathrm{kg}^{-1}$ sand, silt, and clay, respectively. This soil type under this semiarid condition has low organic matter, $N$, and $\mathrm{P}$ contents that can't support a productive agriculture. Soil physical and chemical characteristics of the study area presented in Table 1. The climate of the region is subtropical to semi-arid with an annual average rainfall of $292 \mathrm{~mm}$ out of which more than $70 \%$ occurs as heavy showers during June to September. Mean monthly minimum temperature is $13^{\circ} \mathrm{C}$ in January and maximum temperature is $39^{\circ} \mathrm{C}$ in July. Average temperature, total rainfall, and average relative humidity of research area are presented in Table 2.

Four tillage systems (zero, minimum, conventional, and deep tillage) and four nitrogen levels $\left(0,130,160,190 \mathrm{~kg} \mathrm{ha}^{-1}\right)$ were applied depending on treatments. Tillage systems were kept on
Table 1. Physical and Chemical Properties of the Hafizabad Sandy Clay Loam Soil (mixed, semi-active, isohyperthermic Typic Calciargids) at the research site.

\begin{tabular}{ll}
\hline Soil Properties $(\mathbf{0}-\mathbf{0 . 0 4} \mathbf{~ m})$ & Values \\
\hline Sand (\%) & 53 \\
Silt (\%) & 21 \\
Clay (\%) & 26 \\
Textural Class & Sandy Clay Loam \\
$\mathrm{pH}$ & 7.5 \\
Electrical Conductivity $\left(\mathrm{d} \mathrm{Sm}^{-1}\right)$ & 1.35 \\
Bulk Density $\left(\mathrm{Mg} \mathrm{m}^{-3}\right)$ & 1.45 \\
Organic carbon contents $\left(\mathrm{g} \mathrm{kg}^{-1}\right)$ & 3.5 \\
Soil total N (g kg-1) & 0.40 \\
\hline
\end{tabular}

Table 2. Average temperature, total rainfall and average relative humidity of research area at meteorological cell of University of Agriculture, Faisalabad, Pakistan.

\begin{tabular}{|l|c|c|c|c|c|}
\hline \multirow{2}{*}{ Month } & \multicolumn{3}{|c|}{ Temperature $^{\circ} \mathbf{C}$} & \multirow{2}{*}{$\begin{array}{c}\text { Total Rainfall } \\
(\mathbf{m m})\end{array}$} & RH (\%) \\
\cline { 2 - 4 } & Maximum & Minimum & Mean & \multicolumn{2}{|c|}{} \\
\hline November & 25.7 & 10.8 & 18.2 & 0.70 & 64.7 \\
\hline December & 22.1 & 7 & 14.5 & 0 & 64.4 \\
\hline January & 16.2 & 6 & 11.1 & 0.8 & 82.3 \\
\hline February & 22 & 9.5 & 15.7 & 11.9 & 62.7 \\
\hline March & 30.4 & 16.5 & 23.5 & 8.8 & 57.5 \\
\hline April & 38.4 & 21.4 & 29.9 & 1.3 & 36.8 \\
\hline \multicolumn{7}{|c|}{$2010-2011$} & & \\
\hline November & 27.1 & 10.5 & 18.8 & 0 & 62.3 \\
\hline December & 20.8 & 5.9 & 13.3 & 1.0 & 70.5 \\
\hline January & 15.9 & 4.3 & 10.1 & 0 & 73.4 \\
\hline February & 20.1 & 8.6 & 14.4 & 20.6 & 72.9 \\
\hline March & 26.3 & 13.1 & 19.7 & 6.8 & 59.8 \\
\hline April & 32.0 & 17.1 & 24.8 & 20.9 & 46.9 \\
\hline
\end{tabular}

Data were collected from meteorological cell of UAF.

the main plots, while nitrogen levels were applied to the subplots. Recommended rates of $\mathrm{P}$ and $\mathrm{K}$ were applied as Triple Super Phosphate (TSP) and Sulphate of Potash (SOP) at planting. Nitrogen was applied in three splits. One third of each nitrogen level was applied at planting, the second third at first irrigation and the last third with the second irrigation. Hoeing along with herbicides was used to control weeds. The seeding rate was $110 \mathrm{~kg} \mathrm{ha}^{-1}$ and planting was done using a drill machine with an inter-row spacing of $22.5 \mathrm{~cm}$. the weight variety is called Sahar. The first crop was planted in November 2009 and the second crop in November 2010. The experimental layout was a split plot design with the tillage system as the main plots and the inorganic nitrogen levels as the sub-plots. Each treatment was replicated thrice. The dimension of each treatment plot, sub-plot, was $10 \times 10 \mathrm{~m}$. Soil samples were randomly collected from 0.0-0.05, 0.05-0.15 and 0.15-0.30 m depths before planting and at harvest at six different locations on each plot. Samples from each plot were mixed to form a composite. These samples were analyzed for soil $\mathrm{C}$ and total $\mathrm{N}$ contents. Soil samples were air dried and ground to pass a $2 \mathrm{~mm}$ sieve; then, they were analyzed for total organic carbon and other soil properties. Total organic carbon was determined by potassium 


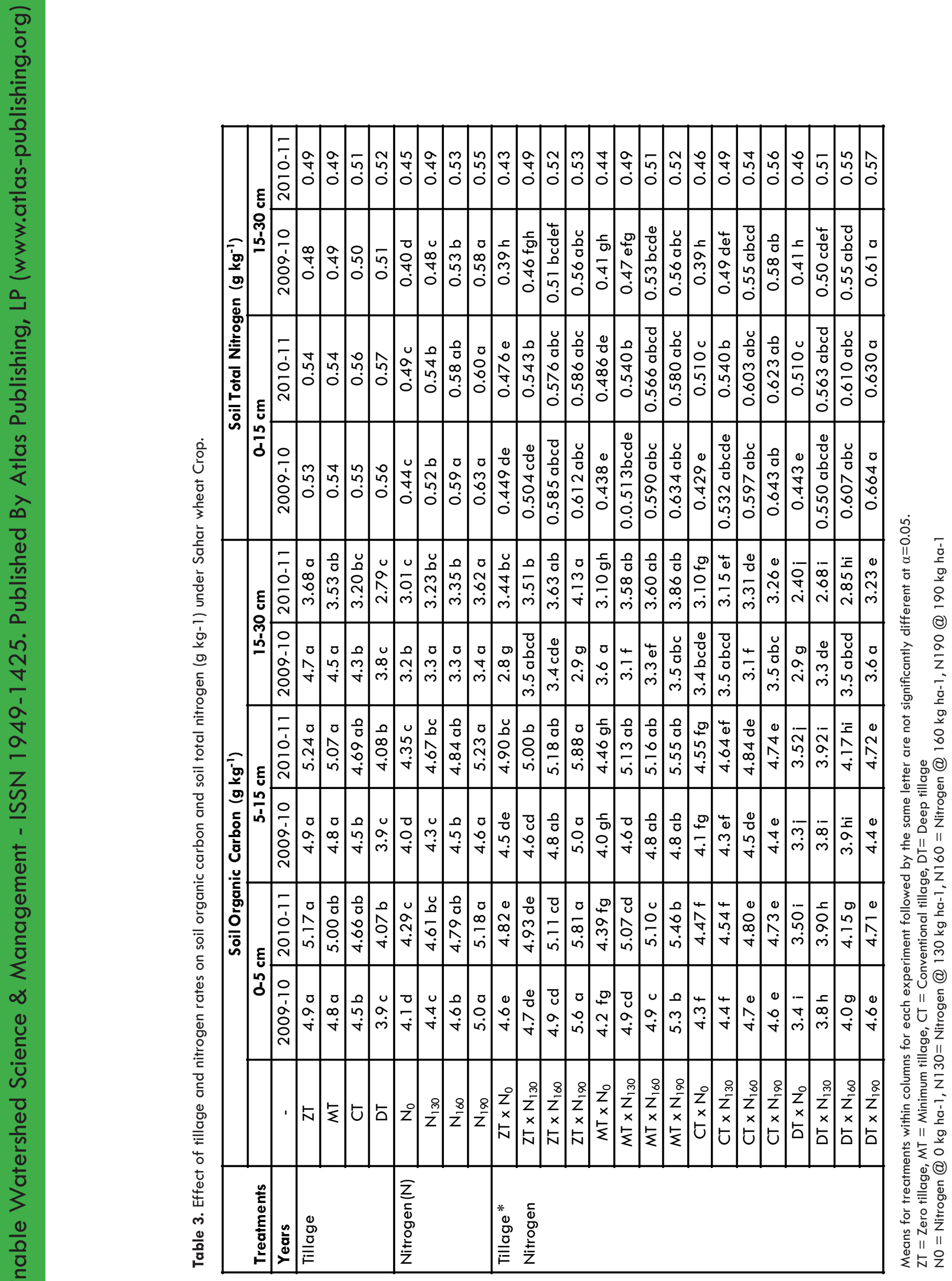


dichromate $\left(\mathrm{K}_{2} \mathrm{Cr}_{2} \mathrm{O}_{7}\right)$ method (Ryan et al., 2001); $\mathrm{pH}$ was determined in water (McLean 1982); electrical conductivity of soil extract was measured by the method developed by Rhoades (1982); and soil texture was determined using Bouyoucos hydrometer method (Moodie et al., 2001); Total $\mathrm{N}$ by Bremner and Mulvancy (1982).

Soil bulk density was determined following the method described by Blake and Hartge (1986). However, nitrogen fertilizer use efficiency (FUE) was calculated using the following equation:

FUE $\left(\mathrm{kg}\right.$ grains $\mathrm{kg}^{-1}$ nutrient $)=$ Yield with fertilizer-Yield in control $(\mathrm{kg}) /$ Nutrient

(Equation 1)

Water use efficiency (WUE) was calculated using the following equation:

WUE $\left(\mathrm{kg} \mathrm{ha}^{-1} \mathrm{~mm}^{-1}\right)=$ Grain yield $\left(\mathrm{kg} \mathrm{ha}^{-1}\right) /$ Water applied (mm)

(Equation 2)

The calculation of the soil carbon ratio, which is a sensitive indicator of soil quality, is calculated as follows:

$\mathrm{SOCs} / \mathrm{TNs}=\sum_{(\mathrm{i}=1)}^{\mathrm{n}}(\mathrm{Ci} / \mathrm{Ni} \times \rho \mathrm{i} \times \mathrm{Ti}) / 10$

(Equation 3)

In this equation, SOCs and TNs are organic carbon storages, and total nitrogen storages $\left(t^{\bullet} \mathrm{ha}^{-1}\right)$ of soil at depth $\mathrm{i}$, respectively; $\mathrm{Ci} / \mathrm{Ni}$ is the organic carbon concentrations and total nitrogen concentrations $\left(\mathrm{g} \mathrm{kg}^{-1}\right)$ in layer-i soil; $\rho \mathrm{i}$ is the soil bulk density of lay-i soil $\left(\mathrm{g} \mathrm{cm}^{-3}\right)$; $\mathrm{Ti}$ is the soil thickness of lay-i soil; $\mathrm{n}$ is the soil layer quantity (Jiang et al., 2005).

\section{Economic and Marginal Analysis}

The data collected from this study were used for economic and marginal analysis. Expenditures on different nutrient sources were as follows: $\mathrm{N}$, US $\$ 0.199 \mathrm{~kg}^{-1} ; \mathrm{P}_{2} \mathrm{O}_{5^{\prime}}$ US $\$ 0.59$ $\mathrm{kg}^{-1} ; \mathrm{K}_{2} \mathrm{O}$, US \$ $0.48 \mathrm{~kg}^{-1}$. Seed, US \$ 43.07; herbicide, US \$ 14.15; harvesting and threshing US $\$ 95.36 \mathrm{Mg}^{-1}$. Irrigation US \$ 176.0. The $\mathrm{N}$ was applied @ 0,130, 160 and $190 \mathrm{~kg} \mathrm{~N}$ $\mathrm{ha}^{-1}$. P and $\mathrm{K}$ were applied @ 85:62 kg $\mathrm{P}_{2} \mathrm{O}_{5}: \mathrm{K}_{2} \mathrm{O} \mathrm{ha}^{-1}$ in all treatments, respectively. DT, US \$148.0, CT, US \$109.4, MT, US \$ 69.1 and ZT, US \$17.2.

Price of the wheat produce is as follows: wheat grain, US\$ $265.5 \mathrm{Mg}^{-1}$; Wheat straw $=$ US $\$ 115.1 \mathrm{Mg}^{-1}$.

\section{Statistical Analysis}

An analysis of variance was performed on data collected from this trial for the split-plot design. Duncan's multiple range test was performed for the mean separation analysis.

\section{Results}

Soil organic $C$ was significantly affected by tillage in the 0-5, 5-15 and 15-30 cm depths during 2009-10 and 2010-
11 (Table 3). Zero tillage had greater amounts of SOC than MT, CT and DT at 0-5, 5-15 and $15-30 \mathrm{~cm}$ during both years. Nitrogen application significantly affected SOC values for $0-5$, 5-1 5 and $15-30 \mathrm{~cm}$ during both years. The higher $\mathrm{N}$ rate treatments, $190-\mathrm{N}$ and $160-\mathrm{N}$, have higher SOC $\left(5.0\right.$ and $4.6 \mathrm{~g} \mathrm{~kg}^{-1}$, respectively) than the $0-\mathrm{N}$ and $130-\mathrm{N}$ treatments (4.1 and 4.4 $\mathrm{g} \mathrm{kg}^{-1}$, respectively) for $0-5 \mathrm{~cm}$ depth during 2009-10. For the $5-15 \mathrm{~cm}$ depth, $\mathrm{N}$ application significantly affected SOC; the $190-\mathrm{N}$ rate treatment $\left(4.6 \mathrm{~g} \mathrm{~kg}^{-1}\right)$ had a greater SOC than the control (4.0 $\left.\mathrm{g} \mathrm{kg}^{-1}\right)$ treatment during 2009-10.

The effect of tillage and nitrogen rates on total nitrogen is shown in Table 3. The soil total nitrogen concentrations at 0-15 and $15-30 \mathrm{~cm}$ depths was not significantly affected by tillage practices during the two growing seasons. Overall, the soil total nitrogen concentrations are higher at $0-15 \mathrm{~cm}$ depth than at 15 $-30 \mathrm{~cm}$ depth. There was a significant positive correlation between nitrogen fertilizer rates and the soil total nitrogen concentrations for the 0-15 and 15-30 soil depths. . In other words, STN for the four $\mathrm{N}$ fertilization treatments and for the two soil layers ranked as follows: $190-\mathrm{N}>160-\mathrm{N}>130-\mathrm{N}>0-\mathrm{N}$.

Soil bulk density was measured separately for different layers. Soil bulk density under DT, CT, MT and ZT was 1.38, 1.42, 1.45 and $1.46 \mathrm{~g} \mathrm{~cm}-3$, respectively, for the top two depths (0-5 and $5-15 \mathrm{~cm}$ ). For the $15-20 \mathrm{~cm}$ depth, soil bulk density was 1.52 under ZT, MT and CT, and 1.48 for the DT treatment.

At 0-5 depth, SOC storage for DT was statistically different from that of $\mathrm{ZT}, \mathrm{MT}$ and $\mathrm{CT}$ treatments. The SOC storage for these latter treatments was statistically the same. However, at 0-15 cm depth, SOC storage was similar for ZT and MT treatment, which were significantly greater than that of $C T$ and DT treatments during the two growing seasons. There were no significant differences between tillage systems at the $0-30 \mathrm{~cm}$ depth, although MT (15.5 + C ha $\left.{ }^{-1}\right)$ had $1.1 \mathrm{tha}^{-1}$ more $\mathrm{C}$ storage than ZT (14.4 t $\mathrm{C} \mathrm{ha-1}$ ) (Table 4) during the first growing season. There was a significant effect of $\mathrm{N}$ application at $0-5 \mathrm{~cm}$ where the $190-\mathrm{N}$ rate $\left(3.60+C\right.$ ha $\left.^{-1}\right)$ had $0.62+C$ ha $^{-1}$ more $C$ than the $0-\mathrm{N}$ rate

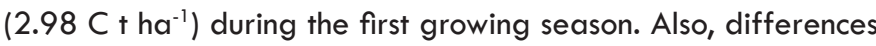
in SOC storage between $\mathrm{N}$ rates were observed at $0-15 \mathrm{~cm}$ and $0-30 \mathrm{~cm}, 1.42$ and $0.9 \mathrm{tha}^{-1}$ or carbon, respectively.

Soil nitrogen storage was not significantly influenced by soil tillage treatments at $0-15 \mathrm{~cm}$ and $0-30 \mathrm{~cm}$ soil depth (Table 4) during 2009-10 and 2010-11. However, soil nitrogen storage was greater in MT at $0-15 \mathrm{~cm}$ soil depth than in $\mathrm{ZT}, \mathrm{CT}$ and DT. Soil nitrogen storage was significantly influenced by soil $N$ treatments in the soil layers evaluated (Table 4), emphasising significantly greater value of soil nitrogen storage with $190-\mathrm{N}$ than $160-\mathrm{N}, 130-\mathrm{N}$ and $0-\mathrm{N}$ at $0-15$ and $15-30 \mathrm{~cm}$ soil layers during both the years.

Plant height was significant affected by tillage practices; however, effect of $\mathrm{N}$ application was non-significant (Table 5). Higher average plant height $(97.7 \mathrm{~cm})$ was recorded with minimum tillage. Average plant height increased from 92.4 to 96.8 $\mathrm{cm}$ with increase in N rates from N0 to N190, respectively. Grain yield was significant affected by $\mathrm{N}$ application; however, effect of tillage was non-significant (Table 5). Grain yield significantly increased from 3.68 to $5.80 \mathrm{Mg} \mathrm{ha}^{-1}$ with increase in $\mathrm{N}$ rates from NO to N160, respectively. There were significant differ- 


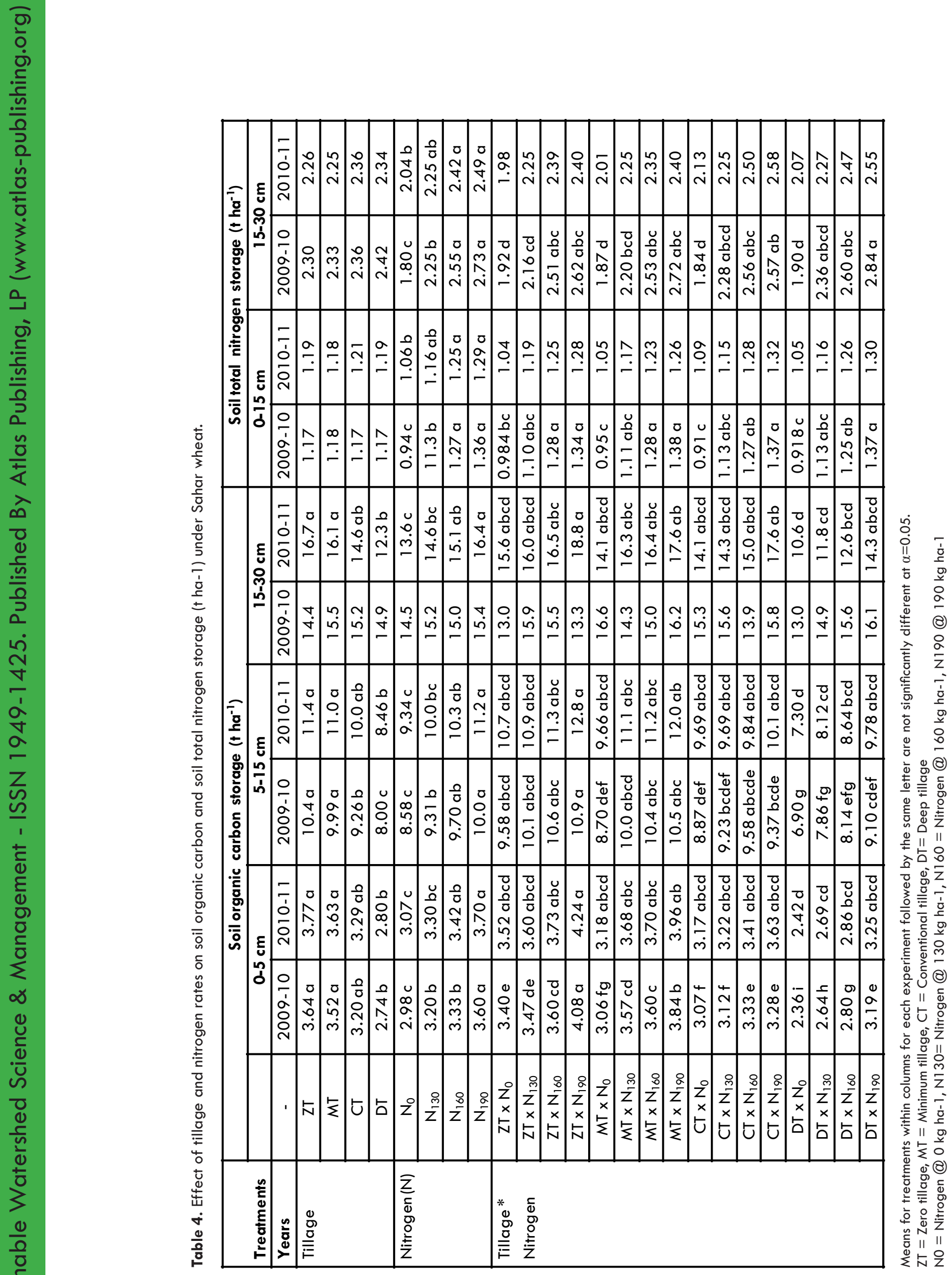


Table 5. Effect of tillage and nitrogen rates on grain yield, harvest index, water use efficiency and fertilizer use efficiency in wheat (Average of two years).

\begin{tabular}{|c|c|c|c|c|c|}
\hline \multicolumn{2}{|c|}{ Treatments } & \multirow{2}{*}{$\begin{array}{c}\begin{array}{c}\text { Plant Height } \\
(\mathbf{c m})\end{array} \\
94.9 \mathrm{ab} \\
\end{array}$} & \multirow{2}{*}{$\begin{array}{c}\begin{array}{c}\text { Grain Yield } \\
\left(\mathbf{M g ~ h a}^{-1}\right)\end{array} \\
5.05 \\
\end{array}$} & \multirow{2}{*}{$\begin{array}{c}\text { Water Use Efficiency } \\
\begin{array}{c}(\mathbf{k g ~ h a} \\
\left.\mathbf{~}^{-1} \mathbf{m}^{-1}\right)\end{array} \\
12.6 \\
\end{array}$} & \multirow{2}{*}{$\begin{array}{c}\begin{array}{c}\text { Fertilizer Use } \\
\text { Efficiency }\end{array} \\
4.12\end{array}$} \\
\hline Tillage & $\mathrm{ZT}$ & & & & \\
\hline & MT & $97.7 \mathrm{a}$ & 5.08 & 12.7 & 4.13 \\
\hline & $\mathrm{CT}$ & $93.4 \mathrm{~b}$ & 5.08 & 12.7 & 4.19 \\
\hline & DT & $95.7 \mathrm{ab}$ & 5.25 & 13.4 & 4.27 \\
\hline \multirow{4}{*}{$\begin{array}{l}\text { Nitrogen } \\
\text { (N) }\end{array}$} & $\mathrm{N}_{0}$ & 92.4 & $3.68 c$ & $9.20 \mathrm{c}$ & - \\
\hline & $\mathrm{N}_{130}$ & 96.1 & $5.32 \mathrm{~b}$ & $13.3 b$ & $5.29 b$ \\
\hline & $N_{160}$ & 96.5 & $5.80 a$ & $14.5 \mathrm{a}$ & $5.78 a$ \\
\hline & $N_{190}$ & 96.8 & $5.66 \mathrm{a}$ & $14.1 \mathrm{a}$ & $5.64 \mathrm{a}$ \\
\hline \multirow{16}{*}{$\begin{array}{l}\text { Tillage* } \\
\text { Nitrogen }\end{array}$} & $\mathrm{ZT} \times \mathrm{N}_{0}$ & 93.03 & $3.63 \mathrm{f}$ & $9.08 \mathrm{~b}$ & - \\
\hline & $\mathrm{ZT} \times \mathrm{N}_{130}$ & 95.17 & 5.46 bcde & $13.6 a$ & 5.43 \\
\hline & $\mathrm{ZT} \times \mathrm{N}_{160}$ & 96.5 & $5.60 \mathrm{abcde}$ & $14.0 a$ & 5.58 \\
\hline & $\mathrm{ZT} \times \mathrm{N}_{190}$ & 95.23 & $5.50 \mathrm{bcde}$ & $13.7 a$ & 5.48 \\
\hline & $M T \times N_{0}$ & 98.6 & $3.74 \mathrm{f}$ & $9.35 \mathrm{~b}$ & - \\
\hline & $M T \times N_{130}$ & 98.3 & $5.30 \mathrm{de}$ & $13.2 \mathrm{a}$ & 5.27 \\
\hline & $M T \times N_{160}$ & 97.97 & $5.68 \mathrm{abcd}$ & $14.2 \mathrm{a}$ & 5.66 \\
\hline & $M T \times N_{190}$ & 96.03 & $5.61 \mathrm{abcde}$ & $14.0 \mathrm{a}$ & 5.59 \\
\hline & $\mathrm{CT} \times \mathrm{N}_{0}$ & 85.3 & $3.50 \mathrm{f}$ & $8.75 \mathrm{~b}$ & - \\
\hline & $\mathrm{CT} \times \mathrm{N}_{130}$ & 98.13 & $5.16 \mathrm{e}$ & $12.9 a$ & 5.13 \\
\hline & $\mathrm{CT} \times \mathrm{N}_{160}$ & 93.33 & $5.93 a b$ & $14.8 \mathrm{a}$ & 5.91 \\
\hline & $\mathrm{CT} \times \mathrm{N}_{190}$ & 97.03 & $5.74 \mathrm{abcd}$ & $14.3 a$ & 5.72 \\
\hline & $\mathrm{DT} \times \mathrm{N}_{0}$ & 92.73 & $3.85 \mathrm{f}$ & $9.63 \mathrm{~b}$ & - \\
\hline & DT $\times N_{130}$ & 92.8 & $5.36 \mathrm{cde}$ & $13.4 \mathrm{a}$ & 5.33 \\
\hline & DT $\times N_{160}$ & 98.27 & $5.99 \mathrm{a}$ & $14.9 a$ & 5.97 \\
\hline & DT $\times N_{190}$ & 99.2 & $5.81 \mathrm{abc}$ & $14.5 \mathrm{a}$ & 5.79 \\
\hline
\end{tabular}

Means for treatments within columns for each experiment followed by the same letter are not significantly different at $\alpha=0.05$. ZT = Zero tillage, $M T=$ Minimum tillage, $C T=$ Conventional tillage, $D T=$ Deep tillage. N0 = Nitrogen @ 0 kg ha-1, N130= Nitrogen @ 130 kg ha-1, N160= Nitrogen @160kg ha-1, N190@190kg ha-1

ences among treatments in case of water use efficiency (Table 5). Water use efficiency was improved with increasing $N$ rate and tillage intensity; and their combined use was also significant. The maximum WUE (14.9 $\left.\mathrm{kg} \mathrm{ha}^{-1} \mathrm{~mm}^{-1}\right)$ was observed in case of treatment receiving $160 \mathrm{~kg} \mathrm{~N} \mathrm{ha}^{-1}$ along with deep tillage. The results of our study revealed that the application of nitrogen fertilizer increased the fertilizer use efficiency (Table 5). The maximum FUE (5.78) was observed in case of treatment receiving $160 \mathrm{~kg} \mathrm{~N} \mathrm{ha}^{-1}$ than the control.

Data regarding economic analysis of wheat yield indicate that the maximum net field benefit of US \$2356.9 $\mathrm{ha}^{-1}$ was achieved from treatment combination DT $\times \mathrm{N} 190$ followed by $\mathrm{CT} \times \mathrm{N} 160$ having US \$2353.9 $\mathrm{ha}^{-1}$ and the lowest (US \$ $1361.9 \mathrm{ha}^{-1}$ ) in the case of CT $\times$ NO treatment (Table 6). Dominance and marginal analysis indicate that marginal rate of return was maximum from the treatment combination $\mathrm{CT} \times \mathrm{N} 160$ followed by DT $\times$ N160 and ZT $\times$ N130, while all control N treatment combinations were un-economical due to higher input cost and low returns (Table 7).

\section{Discussion}

There were significant differences in response of wheat yield, SOC, and STN to tillage and $\mathrm{N}$ rates. The impact of tillage was significant at three soil layers $(0-5,5-15$ and $15-30 \mathrm{~cm})$ where SOC was greater under ZT than under DT. Several authors have found that the tillage impact is confined to the soil surface (Deen and Kataki, 2003; Fabrizzi et al., 2003; Mikha and Rice, 2004; Wright and Hons, 2004). Results from our research show the positive impact that minimum and zero-tillage systems have on SOC accumulation. The limited soil disturbance and better aggregation (McVay et al., 2006) under these systems could explain the greater C storage than CT and DT systems. Nitrogen fertilization significantly affected soil organic where the highest rate of $\mathrm{N}$ application had the greatest soil organic carbon, which can be attributed to greater amount of residues produced with increased N. Russell et al. (2005) also reported significant effects of $\mathrm{N}$ fertilization rate on $\mathrm{SOC}$ pool in the $0-15 \mathrm{~cm}$ depth. This indicated that long-term applications of inorganic fertilizers are unable to maintain levels of SOC and nutrients under conventional management with no aboveground crop residues re- 


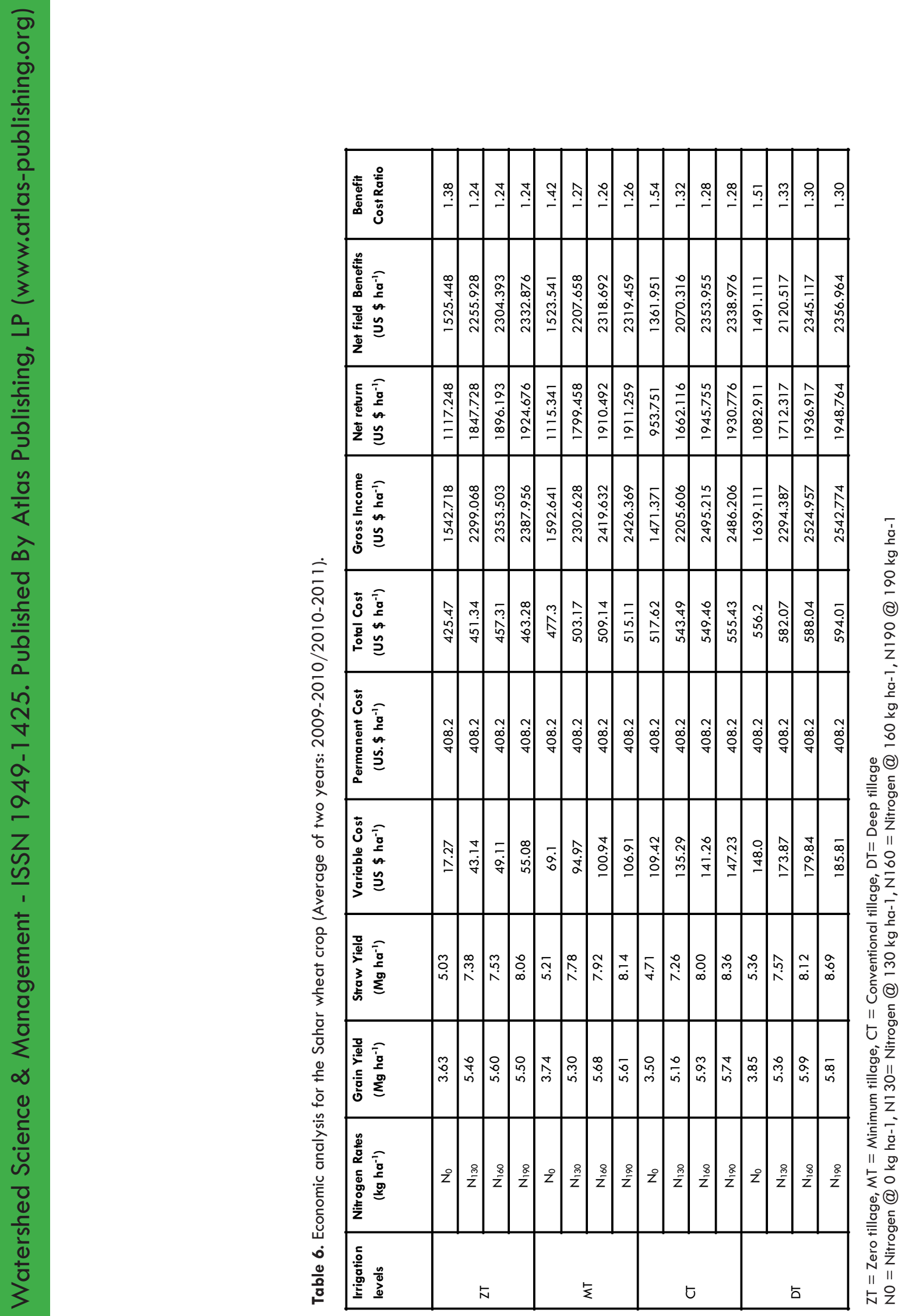


Table 7. Dominance and Marginal analysis for the Sahar wheat crop (Average of two years: 2009-2010/2010-2011).

\begin{tabular}{|c|c|c|c|c|c|c|c|}
\hline $\begin{array}{l}\text { Irrigation } \\
\text { Levels }\end{array}$ & 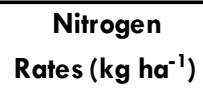 & $\begin{array}{l}\text { Variable Cost } \\
\left.\text { (US . } \$ h^{-1}\right)\end{array}$ & $\begin{array}{l}\text { Net Field Benefits } \\
\quad \text { (US } \$ \mathrm{ha}^{-1} \text { ) }\end{array}$ & $\begin{array}{c}\text { Marginal Cost } \\
\text { that vary }\end{array}$ & $\begin{array}{l}\text { Marginal Net } \\
\text { Field Benefits }\end{array}$ & $\begin{array}{c}\text { Marginal Rate } \\
\text { of Return }\end{array}$ & $\begin{array}{l}\text { Dominated } \\
\text { Treatments }\end{array}$ \\
\hline$\overline{Z T}$ & $\mathrm{~N}_{0}$ & 17.27 & 1525.448 & - & - & - & - \\
\hline$\overline{Z T}$ & $\mathrm{~N}_{130}$ & 43.14 & 2255.928 & 25.87 & 730.48 & 28.23 & \\
\hline ZT & $N_{160}$ & 49.11 & 2304.393 & 5.97 & 48.465 & 8.11 & \\
\hline ZT & $N_{190}$ & 55.08 & 2332.876 & 5.97 & 28.483 & 4.77 & \\
\hline MT & $N_{0}$ & 69.1 & 1523.541 & - & - & - & $D$ \\
\hline MT & $N_{130}$ & 94.97 & 2207.658 & 25.87 & 684.117 & 26.44 & \\
\hline MT & $N_{160}$ & 100.94 & 2318.692 & 5.97 & 111.034 & 18.59 & \\
\hline MT & $N_{190}$ & 106.91 & 2319.459 & 5.97 & 0.767 & 0.128 & \\
\hline $\mathrm{CT}$ & $\mathrm{N}_{0}$ & 109.42 & 1361.951 & - & - & - & $\mathrm{D}$ \\
\hline$\overline{C T}$ & $\mathrm{~N}_{130}$ & 135.29 & 2070.316 & 25.87 & 708.365 & 27.38 & \\
\hline $\mathrm{CT}$ & $N_{160}$ & 141.26 & 2353.955 & 5.97 & 283.639 & 47.51 & \\
\hline$\overline{C T}$ & $N_{190}$ & 147.23 & 2338.976 & - & - & - & $\mathrm{D}$ \\
\hline DT & $\mathrm{N}_{0}$ & 148.0 & 1491.111 & - & - & - & $D$ \\
\hline DT & $N_{130}$ & 173.87 & 2120.517 & 25.87 & 629.406 & 24.32 & \\
\hline DT & $N_{160}$ & 179.84 & 2345.117 & 5.97 & 224.6 & 37.62 & \\
\hline DT & $\mathrm{N}_{190}$ & 185.81 & 2356.964 & 5.97 & 11.847 & 1.984 & \\
\hline
\end{tabular}

$\mathrm{ZT}=$ Zero tillage, $\mathrm{MT}=$ Minimum tillage, $\mathrm{CT}=$ Conventional tillage, $\mathrm{DT}=$ Deep tillage

NO= Nitrogen @ 0 kg ha- ${ }^{-1}$ N130= Nitrogen @130 kg ha-1, N160= Nitrogen @ $160 \mathrm{~kg} \mathrm{ha}^{-1}$, N190@190 kg ha.

turning to the soil (Su et al. 2006). Results of this study revealed that increasing the nitrogen rates also increased soil total $\mathrm{N}$. The increase in soil $\mathrm{N}$ might be due to residual buildup of soil nitrogen by continuous application of inorganic fertilizer. Hati et al. (2008) also reported increase in total $\mathrm{N}$ content with increasing $\mathrm{N}$ rates in the uppermost soil layer. These results are in accordance with those of Agbede et al. (2008) who found that higher nitrogen fertilizer levels resulted in higher concentrations of available $\mathrm{P}, \mathrm{K}, \mathrm{N}$ and organic $\mathrm{C}$ than the control treatments in soil. Tillage and nitrogen fertilizer also improved soil organic carbon storage. More soil organic carbon storage under zero tillage might be due to high amounts of biomass added to the soil, causes minimal soil disturbance, conserves soil and water, improves soil structure, and enhances soil fauna activity (Six et al., 2000). Lal et al. (1998) summarized the rate of accumulation of soil organic carbon (SOC) stock under NT at 300-800 $\mathrm{kg} \mathrm{SOC} \mathrm{ha-1} \mathrm{year-1.} \mathrm{The} \mathrm{introduction} \mathrm{of} \mathrm{conservation} \mathrm{tillage} \mathrm{in-}$ creases the organic carbon storage in the cultivated layer 10 $-20 \mathrm{~cm}$ ) from 0.19 to $0.81 \mathrm{Mg} \mathrm{ha}^{-1}$ year $^{-1}$ (Baker et al., 2007; Bayer et al., 2006; Zhang et al., 2009). Zero and minimum tillage and nitrogen fertilization can improve $C$ and $N$ storage in the surface soil (Allmaras et al., 2000; Sainju et al., 2006), while conventional and $\mathrm{N}$ fertilization decreases soil organic matter level by increasing carbon and nitrogen mineralization and limiting $C$ and $N$ inputs (Balesdent et al., 1990; Cambardella and
Elliott, 1993). Results of this study revealed that increasing the nitrogen rates also increased plant height, grain yield, WUE and FUE in wheat crop, over control. Increase in plant height at high fertilizer level might be due to proper nutrition availability which resulted in increase in vegetative growth of the plants. This might be due to the cell division and enlargement which might be stimulated by nitrogen nutrition. Similar result were recorded by Maqsood et al. (2000) who concluded that application of nitrogen at the rate of $125 \mathrm{~kg} \mathrm{ha}^{-1}$ produced significantly taller plants $\left(97.6 \mathrm{~cm}\right.$ ) than 100 and $75 \mathrm{~kg} \mathrm{~N} \mathrm{ha}^{-1}$, yet it did not significantly differ from treatment $150 \mathrm{~kg} \mathrm{~N} \mathrm{ha}^{-1}(97.1 \mathrm{~cm})$. These results are in conformity with those noted by Shivay and Singh. (2000), who reported that plant height of maize decreased under minimum tillage. Similarly, Singh and Sharma (2001) also observed that grain yield and yield-attributing parameters significantly increased with increasing nitrogen levels up to $150 \mathrm{~kg}$ $\mathrm{ha}^{-1}$. Results of this study are also in line with those of Kumbhar et al. (2007) who found that increase in levels of fertilizer at 150 $50 \mathrm{NP} \mathrm{kg} \mathrm{ha}{ }^{-1}$ gradually increased grain yield (3198.2 $\mathrm{kg} \mathrm{ha}^{-1}$ ). This could have been due to both the higher nutrient availability from fertilizer and the improvement in the soil physical conditions due to tillage. FUE also increased by recommended dose of NPK compared to less or more application of nitrogen (Raza et al., 2005). Daniels and Scott (1991) also found an average WUE of $9.66 \mathrm{~kg} \mathrm{ha}^{-1} \mathrm{~mm}^{-1}$ of water. 


\section{Conclusion}

A study was conducted to assess the effect of tillage and nitrogen application rates on the soil organic carbon, soil total nitrogen in the surface soil, and yield of wheat in a sandy clay loam soil. Results obtained from this study show that tillage practices and fertilizer application rates affected the concentrations of soil organic carbon and total nitrogen in the surface soil, with higher application rates leading to greater accumulations of residual nitrogen and organic carbon.

Grain yield was significantly increased in response to nitrogen rates and tillage intensity with higher grain yields occurring when deep tillage was combined with nitrogen fertilizer. Zero tillage enhances the SOC and STN at 0-30 cm depth, compared with conventional and deep tillage measure sequestrates more carbon and nitrogen, this is helpful to the buildup and storage of SOC and nitrogen, consequently it is a valuable tillage measure and its further popularization is worth.

\section{Acknowledgements}

The authors acknowledge the enabling role of Higher Education Commission, Islamabad for providing funds under "National Research Programme for Universities" in carrying and completing this research work. The authors also wish to acknowledge the help of Professor Ali Fares of the University of Hawaii-Manoa.

\section{References}

Agbede TM, SO Ojeniyi, and AJ Adeyemo (2008). Effect of poultry manure on soil physical and chemical properties, growth and grain yield of sorghum in southwest, Nigeria Americ. Eurasian Journal of Sustainable Agriculture 2: 72-77.

Allmaras RR, HH Schomberg, CJ Douglas, and TH Dao (2000) Soil organic carbon sequestration potential of adopting conservation tillage in U.S. croplands. Journal of Soil Water Conservation 55: 365-373.

Baker JM, TE Ochsner, and RT Venterea (2007) Tillage and soil carbon sequestration-What do we really know. Agriculture Ecosystem Environment 118: 1-5.

Balesdent J, A Mariotti, and D. Boisgontier (1990) Effect of tillage on soil organic carbon mineralization estimated from 13C abundance in maize fields. Journal of Soil Science 41:587-596.

Bayer C, L Martin-Neto, and J Mielniczuk (2006) Carbon sequestration in two Brazilian Cerrado soils under no-till. Soil and Tillage Research 86: 237-245.

Blake GR and KH Hartge (1986) Bulk density. In: Klute, A. (ed.), Methods of Soil Analysis, pp: 363-375, Part I. Agron. 9. ASA, Madison, WI, USA.

Bremner JM and CS Mulvancy (1982) Nitrogen Total. In: Page, A.L. (ed.), Methods of Soil Analysis, Agronomy No. Part 2: Chemical and microbiological properties, 2nd edition, pp: 595-624. American Society Agronomy, Madison, WI, USA.

Caldeira K, MG Morgan, D Baldocchi, PG Brewer, CTA Chen, GJ Nabuurs, N Nakicenovic, and GP Robertson (2004) A portfolio of carbon management options. p.103-129. In: C. B. Field and M. R. Raupauch (ed.) The Global carbon cycle. Island Press, Washington, DC. USA.

Cambardella CA, and ET Elliott (1993) Carbon and nitrogen distribu- tion in aggregates from cultivated and native grassland soils. Soil Science Society of American Journal 57: 1071-1076.

Campbell CA, RP Zentner, BC Liang, G Roloff, EC Gregorich, and B Blomer (2000) Organic $C$ accumulation in soil over 30 years in semiarid southwestern Saskatchewan -Effect of crop rotations and fertilizers. Canadian Journal of Soil Science 80: 179-192.

Clapp CE, RR Allmaras, MF Layese, DR Linden, and RH Dowdy (2000) Soil organic carbon and $13 \mathrm{C}$ abundance as related to tillage, crop residue, and nitrogen fertilizer under continuous corn management in Minnesota. Soil and Tillage Research 55: 127-1 42.

Daniels MB, and HD Scott (1991) Water use efficiency of doublecropped wheat and soybean. Agronomy Journal 8: 564-570.

Davidson EA and IL. Ackerman (1993) Changes in soil carbon inventories following cultivation of previously untilled soils. Biogeochemistry 20: 161-193.

Deen W, and PK Kataki (2003) Carbon sequestration in long-term conventional vs. conservation tillage experiment. Soil and Tillage Research 74: 143-150.

Fabrizzi KP, FO Garcia, and JL Costa (2005) Soil water dynamics, physical properties and corn and wheat responses to minimum and no tillage systems in the southern Pampas of Argentina. Soil and Tillage Research 81: 57-69.

Fabrizzi KP, A Moron, and FO Garcia (2003) Soil carbon and nitrogen organic fractions in degraded vs. non-degraded Mollisols in Argentina. Soil Science Society of American Journal 67: 1831-1841.

Franzluebbers AJ, GW Langdale, and HH Schomberg (1999) Soil carbon, nitrogen, and aggregation in response to type and frequency of tillage. Soil Science Society of American Journal 63: 349-355.

Hati KM, A Swarup, B Mishra, MC Manna, RH Wanjari, KG Mandal, and AK Misra (2008) Impact of long-term application of fertilizer, manure and lime under intensive cropping on physical properties and organic carbon content of an Alfisol. Geoderma 148: 173-179.

Ishaq M, M Ibrahim, and R Lal (2002) Tillage effects on soil properties at different levels of fertilizer application in Punjab, Pakistan. Soil and Tillage Research 68: 93-99.

Jiang Y, YG Zhang, and W J Liang (2005) Profile distribution and storage of soil organic carbon in an Aquic Brown soil as affected by land use. Scientia Agricultura Sinica 4: 199-206.

Kumbhar AM UA Buriro, FC Oad, and QI Chachar (2007) Yield parameters and $\mathrm{N}$-uptake of wheat under different fertility levels in legume rotation. Journal of Agriculture Technology 3: 323-333.

Lal R, and JM Kimble (1997) Conservation tillage for carbon sequestration. Nutrient Cycling in Agroecosystems 49: 243-253.

Lal R (2003) Global potential of soil carbon sequestration to mitigate the greenhouse effect. Critical Review Plant Science 22: 151-184.

Lal R (2010) A dual response of Conservation Agriculture to Climate Change: Reducing $\mathrm{CO}_{2}$ Emissions and the carbon sink. In: Proceedings of the European Congress on Conservation Agriculture: Towards agro-environmental climate and energetic sustainability. Edición del Ministerio de Medio Ambiente y Medio Rural y Marino, en Coedición con la Asociación Española de Agricultura de Conservación/ suelos vivos. Madrid, Spain, pp. 3-18.

Lal R, RF Follett, JM Kimble, and CV Cole (1998) The Potential of US Cropland to Sequester Carbon and Mitigate the Greenhouse Effect. Lewis Publisher, Boca Raton, FL, 128 pp.

Maqsood M, M Akbar, MT Mahmood, and A Wajid (2000) Yield and quality response of wheat to different nitrogen doses in rice-wheat cropping system. International Journal of Agriculture and Biology 2: 107-108.

McLean EO (1982) Soil pH and Lime Requirement, Methods of Soil Analysis, Part 2, Chemical and Microbiological Properties, 2nd edition, pp: 199-224. Agronomy Monograph No. 9, Madison, WI. 
McVay KA, JA Budde, KP Fabrizzi, MM Mikha, CW Rice, AJ Schlegel, DE Peterson, DW Sweeney, and C Thompson (2006) Management effects on soil physical properties in long-term tillage studies in Kansas. Soil Science Society of American Journal 70: 434-438.

Mikha MM, and CW Rice (2004) Tillage and manure effects on soil and aggregateassociated carbon and nitrogen. Soil Science Society of American Journal 68: 809-816.

Moodie RE, RW Smith, and RA MacGreery (1959) Laboratory Manual of Soil Fertility. State College Washington, Mimeograph, Pullman, WA, USA. p.175.

Onemli F (2004) The effects of soil organic matter on seedling emergence in sunflower (Helianthus annuus L.). Plant Soil Environment 50: 494-499.

Raza W, S Yousaf, A Niaz, MK Rasheed, and I Hussain (2005) Subsoil compaction effects on soil properties, nutrient uptake and yield of maize fodder (Zea mays L.). Pakistan Journal of Botany 37: 933940.

Reicosky DC (2003) Tillage-induced $\mathrm{CO}_{2}$ emissions and carbon sequestration: effect of secondary tillage and compaction. In: L., GarciaTorres, J. Benites, A. Martinez-Vilela, A. Holgado-Cabrera (Eds.), Conservation Agriculture. Kluwer Acad. Pub., Dordrecht, the Netherlands, pp. 291-300.

Rhoades JD (1982) Cation Exchange Capacity, Methods of Soil Analysis, Part 2, Chemical and Microbiological Properties, 2nd edition. Agronomy Monograph No. 12.

Russell AE, DA Laird, TB Parkin, and AP Mallarino (2005) Impact of nitrogen fertilization and cropping system on carbon sequestration in Midwestern Mollisols. Soil Science Society of American Journal 69: 413-422.

Ryan J, G Estefan, and a Rashid (2001) Soil and Plant Analysis Laboratory Manual. 2nd Ed. Interational Center for Agicultural Research in the Dry Areas (ICARDA). Alleppo, Syria, P. 46- 48.

Sainju UM, BP Singh, and S Yaffa (2002) Soil organic matter and tomato yield following tillage, cover cropping, and nitrogen fertilization. Agronomy Journal 94: 594-602.

Sainju UM, BP Singh, WF Whitehead, and S Wang (2006) Carbon supply and storage in tilled and non-tilled soils as influenced by cover crops and nitrogen fertilization. Journal of Environmental Quality 35: 1507-1517.

Schlesinger WH (2000) Soil respiration and the global carbon cycle. Biogeochemistry 48: 7-20.

Shivay YS, and RP Singh (2000) Growth, yield attributes, yields and nitrogen uptake of maize (Zea mays L.) as influenced by cropping systems and nitrogen levels. Annals of Agricultural Research 21: 494-498.

Singh KN, and DP Sharma (2001) Response of wheat to nitrogen and potassium in saline soils. Experimental Agriculture 37: 417-427.

Six J, ET Eliott, and K Paustian (2000) Soil macroaggregate turnover and microaggregate formation: a mechanism for $C$ sequestration under no-tillage agriculture. Soil Biology and Biochemistry 32: 2099-2103.

Su YZ, F Wang, DR Suo, ZH Zhang, and Du MW (2006) Long-term effect of fertilizer and manure application on soil-carbon sequestration and soil fertility under the wheat-maize cropping system in northwest China. Nutrient Cycling in Agroecosystems 75: 285-295.

Wright AL, and FM Hons (2004) Soil aggregation and carbon and nitrogen storage under soybean cropping sequences. Soil Science Society of American Journal 68: 507-513.

Zhang XK, XF Zhao, and WJ Liang (2009) Profile distribution and storage of soil organic carbon and total nitrogen under conservation tillage in Northwest Liaoning, China. American- Eurasian Journal of Sustainable Agriculture 3: 630-636. 